\title{
molecules
}

ISSN 1420-3049

www.mdpi.com/journal/molecules

Article

\section{Synthesis of a New Chiral Pyrrolidine ${ }^{\dagger}$}

\section{Mari Fe. Flores, Marta G. Núñez, Rosalina F. Moro, Narciso M. Garrido, Isidro S. Marcos, Enrique F. Iglesias, Pilar García and David Díez * \\ Departamento de Química Orgánica, Universidad de Salamanca, Plaza de los Caídos 1-5, 37008, Salamanca, Spain}

$\dagger$ This paper is dedicated to Prof. Pelayo Camps on occasion of his $65^{\text {th }}$ birthday.

* Author to whom correspondence should be addressed; E-Mail: ddm@usal.es; Tel.: +34-923-294-474; Fax: +34-923-294-574.

Received: 8 December 2009; in revised form: 2 February 2010 / Accepted: 5 March 2010 / Published: 9 March 2010

\begin{abstract}
The synthesis of a new chiral pyrrolidine has been performed using 2,3-O-isopropylidene-D-erythronolactol as a suitable starting material.
\end{abstract}

Keywords: organocatalysis; pyrrolidines; sulfones; nitrones

\section{Introduction}

In the last years there has been a growing interest in organocatalysis [1-6], a new field which has quickly attracted researchers' attention due to its potential for saving costs, time and energy compared to classic catalysis. Among the many known organocatalysts L-proline is perhaps the one which has been most studied. This fact has led to the appearance of many analogues [7-14]. In the seminal paper of List, Lerner and Barbas III [15], it is described how in the aldol reaction the catalytic activity of L-proline increases using trans-4-hydroxy-L-proline and also how the enantiomeric excess reverses using cis-4-hydroxy-D-proline, (Figure 1). 
Figure 1. L-proline and two analogues.

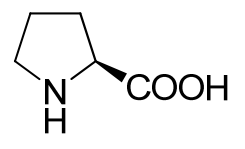

L-proline

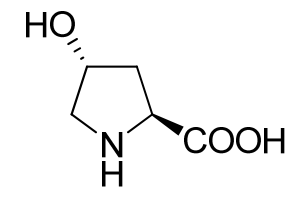

trans-4-Hydroxy-L-proline<smiles>O=C(O)[C@H]1C[C@@H](O)CN1</smiles>

cis-4-Hydroxy-D-proline

In our research group we have achieved the synthesis of several chiral pyrrolidines from sulfonylbutadiene 1 or 2,3-O-iso-propylidene-D-erythronolactol (2) (Scheme 1).

Scheme 1. Synthesis of several pyrrolidines from a sulfonylbutadiene or 2,3-O-isopropylidene-D-erythronolactol.

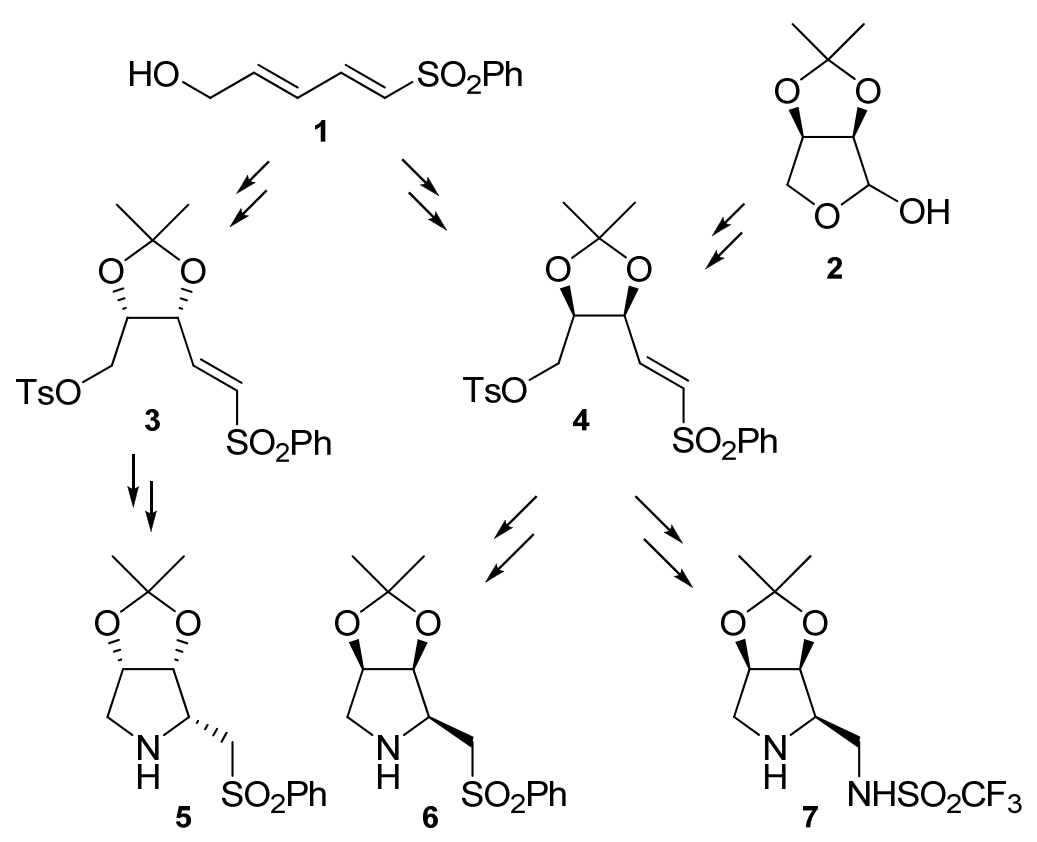

Starting from sulfonylbutadiene 1, pyrrolidines $\mathbf{5}$ and $\mathbf{6}$ were obtained through vinyl sulfones $\mathbf{3}$ and 4, respectively [16-17]. In order to increase the yields, a new route for the synthesis of compound 6 was devised starting from 2,3-O-iso-propylidene-D-erythronolactol (2) through vinylsulfone 4 [18]. This pyrrolidine 6 has been proved to be an organocatalyst for the intramolecular oxa-Michael reaction [19-20]. Moreover, compound 7, which has been reported to catalyze Michael reactions [21], has been synthesized from intermediate vinylsulfone 4 (Scheme 1).

\section{Results and Discussion}

In this paper we describe our studies on the synthesis of the epimer at C-2 of pyrrolidine $\mathbf{6}$, as we are interested in comparing the properties of both diastereoisomers in organocatalytic reactions. In previous studies with PPY-derivatives, we had observed the epimerization of that stereogenic center when it was treated with bases [22]. Taking this into account, we first tried the epimerization at C-2 in compound $\mathbf{8}$, obtained directly from $\mathbf{4}$ by treatment with benzylamine. However, although several 
bases were used, none of them gave the epimerization. Therefore, we devised the following synthesis for the required compound $\mathbf{1 2}$ (Scheme 2).

Scheme 2. Epimerization of C-2 in compound 8.

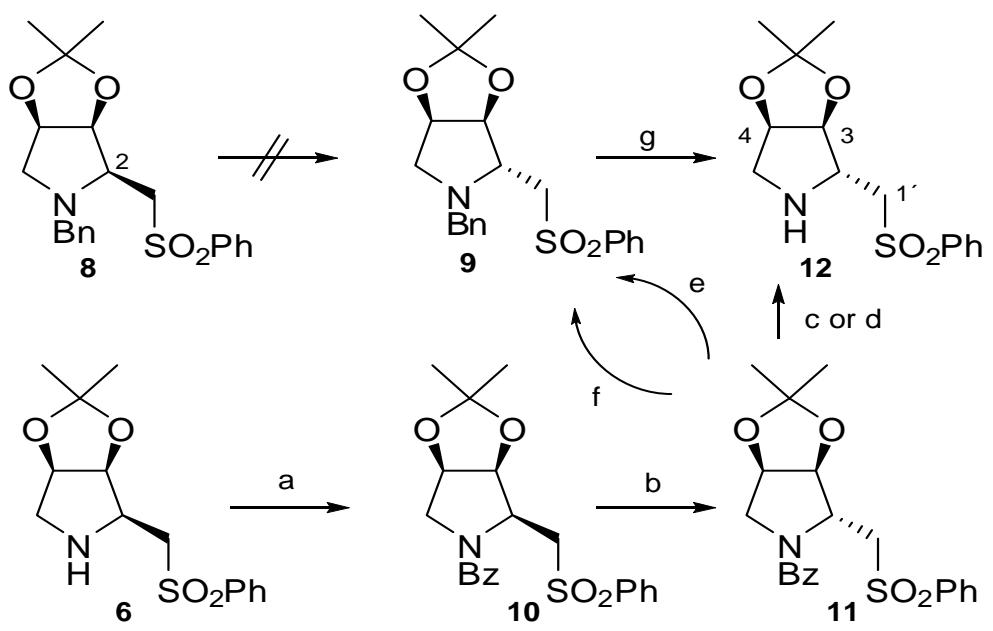

a. PhCOCl, Py., $0{ }^{\circ} \mathrm{C}$-r.t., $97 \%$; b. n-BuLi, THF, $-78^{\circ} \mathrm{C}$-r.t., $50 \%$; c $\mathrm{NH}_{2}-\mathrm{NH}_{2}$, EtOH, reflux, $0 \%$; d. $\mathrm{HCl} 6 \mathrm{M}$, reflux, $0 \%$; e. $\mathrm{LiAlH}_{4}$, THF, $0{ }^{\circ} \mathrm{C}$-r.t., $30 \%$; f. $\mathrm{BH}_{3} \cdot \mathrm{THF}$, THF, $0{ }^{\circ} \mathrm{C}-40{ }^{\circ} \mathrm{C}, 15 \%$; g. $\mathrm{H}_{2}$, $\mathrm{Pd} / \mathrm{C}, \mathrm{MeOH}$, r.t., $80 \%$.

Benzoylation of pyrrolidine $\mathbf{6}$ gave derivative $\mathbf{1 0}$ as outlined in Scheme 2. When this compound was submitted to treatment with $n-\mathrm{BuLi}$, the $\mathrm{C}-2$ epimer 11 was obtained in moderate yield. Once the required stereochemistry at C-2 in $\mathbf{1 1}$ was achieved, we proceeded to deprotect the nitrogen to obtain the desired pyrrolidine 12. This step was not as simple as it was thought initially, since the desired direct debenzoylation did not take place under several conditions. Finally, it was necessary to reduce the benzoyl to benzyl group and then deprotect under the usual conditions. Although, the final deprotection took place in good yield, the previous transformation from benzoyl to benzylderivative was only achieved in low yield, making useless this procedure to synthesise $\mathbf{1 2}$.

Scheme 3. Synthesis of 12 from 2,3-O-iso-propylidene-D-erythronolactol.

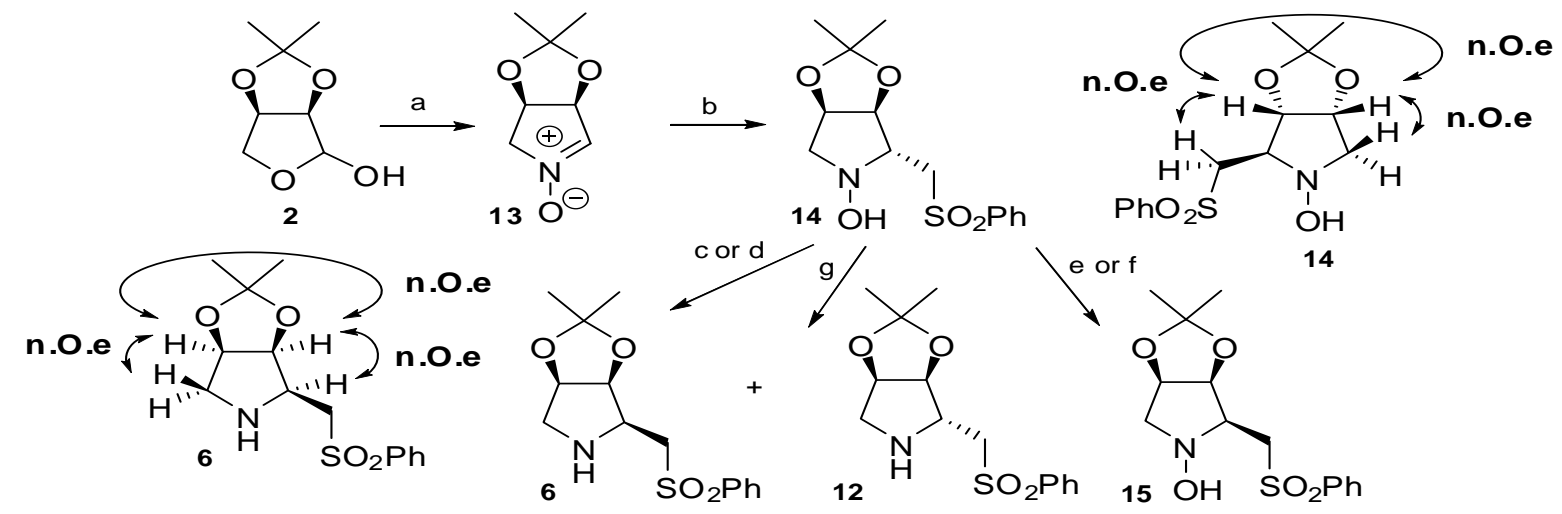

a. 1. $\mathrm{NH}_{2} \mathrm{OSiMe}{ }_{2}$ t-Bu, Py., r.t., 15 h.; 2. $\mathrm{MsCl}, 0{ }^{\circ} \mathrm{C}, 2 \mathrm{~h}, 50 \%$; b. $\mathrm{MeSO}_{2} \mathrm{Ph}, \mathrm{n}-\mathrm{BuLi}$, THF, $-78{ }^{\circ} \mathrm{C}$, $48 \%$; c. $\mathrm{H}_{2}, \mathrm{Pd}(\mathrm{OH})_{2} / \mathrm{C}, \mathrm{HCl} / \mathrm{MeOH}, 4$ atm, $27 \%$; d. $\mathrm{H}_{2}, \mathrm{Pd} / \mathrm{C}, \mathrm{MeOH}, 39 \%$; e. In, $\mathrm{NH}_{4} \mathrm{Cl} / \mathrm{EtOH}$, reflux, $24 \mathrm{~h}, 92 \%$; f. $\mathrm{Zn}, \mathrm{NH}_{4} \mathrm{Cl} / \mathrm{MeOH}$, reflux, $2 \mathrm{~h}, 50 \%$; g. $\mathrm{In}\left(\right.$ cat), $\mathrm{Zn}, \mathrm{NH}_{4} \mathrm{Cl} / \mathrm{MeOH}$ reflux or r.t., see Table 1. 
Therefore, we devised a new synthesis of compound 12 starting from 2,3-O-iso-propylidene-Derythronolactol (2). Goti [23-25] and Wightman and Closa [26-28] have obtained nitrone 13 from compound 2. Besides, Merino and Goti have applied this versatile nitrone to the synthesis of iminocyclitols, pyrrolizidines and indolizidines [29-30], observing that the addition of organometallics to $\mathbf{1 3}$ took place to give the trans compounds. With this procedure in mind, we were able to achieve the desired compound $\mathbf{1 2}$ in a simple manner, as depicted in Scheme 3.

When compound 13 was treated with lithio(phenylsulfonyl)methane, only hydroxylamine 14 was obtained stereoselectively in moderate yield. The stereochemistry of $\mathbf{1 4}$ was established studying its NMR spectra (whose assignment is given in the Experimental section) and by the observation of the nOes that this molecule displays (Scheme 3). The nOes of the enantiomer of compound $\mathbf{6}$ has already been reported by our research group [16]. Once this compound 14 was synthesized, different reduction conditions to obtain the pyrrolidine ring were tested.

Hydrogenation under different conditions either $\mathrm{Pd}(\mathrm{OH})_{2}$ or $\mathrm{Pd}$ on carbon only leads to the pyrrolidine 6. When 14 was submitted to reduction with stoichiometric indium or with zinc, hydroxylamine 15 with inversion at C-2 was obtained. Thus, it was necessary to choose the adequate conditions to reduce the hydroxylamine to the required pyrrolidine 12 without epimerization at C-2. This was achieved using catalytic indium and stoichiometric Zn [29-31] (Table 1, entry 8).

Table 1. Reduction conditions of hydroxylamine $\mathbf{1 4}$ to pyrrolidines $\mathbf{6}$ and $\mathbf{1 2 .}$

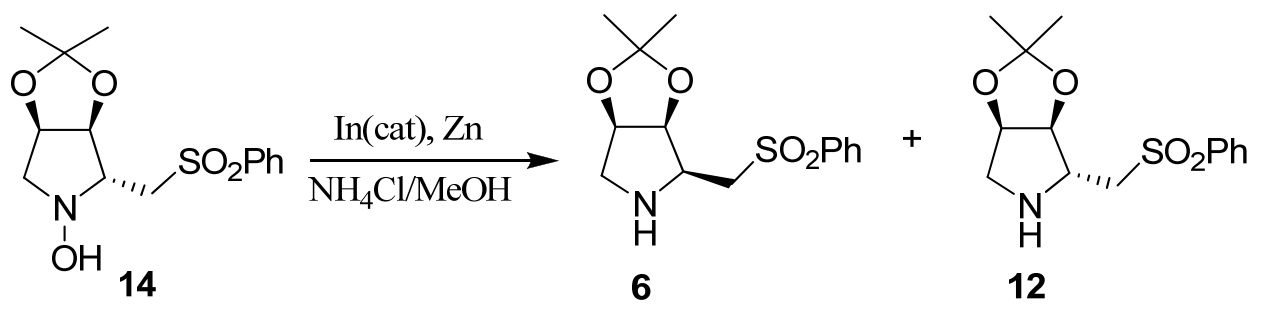

\begin{tabular}{|c|c|c|c|c|c|}
\hline Entry & $\begin{array}{c}\text { Zn } \\
\text { Equiv. }\end{array}$ & $\mathbf{T}^{\text {a }}$ & $\mathbf{t}(\mathbf{h})$ & $\begin{array}{c}\boldsymbol{\eta} \\
(\mathbf{\%})\end{array}$ & $\begin{array}{c}\text { Ratio } \\
\mathbf{6 / 1 2}\end{array}$ \\
\hline $\mathbf{1}$ & 6 & Reflux & 1 & 15 & $40 / 60$ \\
$\mathbf{2}$ & 4 & Reflux & 2 & 10 & $36 / 64$ \\
\hline $\mathbf{3}$ & 4 & Reflux & 1 & 15 & $30 / 70$ \\
\hline $\mathbf{4}$ & 4 & Reflux & 0.5 & $\mathrm{ND}^{\mathrm{a}}$ & $\mathrm{ND}^{\mathrm{a}}$ \\
\hline $\mathbf{5}$ & 2 & Reflux & 1 & $\mathrm{ND}^{\mathrm{a}}$ & $\mathrm{ND}^{\mathrm{a}}$ \\
\hline $\mathbf{6}$ & 2 & Reflux & 1.5 & 10 & $40 / 60$ \\
\hline $\mathbf{7}$ & 2 & Reflux & 2 & 20 & $15 / 85$ \\
\hline $\mathbf{8}$ & 4 & r.t. & 5.5 & 40 & $5 / 95$ \\
\hline $\mathbf{9}$ & 3 & r.t. & 4 & 8 & $45 / 55$ \\
$\mathbf{1 0}$ & 2 & r.t. & 4 & $\mathrm{ND}^{\mathrm{a}}$ & $\mathrm{ND}^{\mathrm{a}}$ \\
\hline \multicolumn{7}{|c}{ a Not determined. } \\
\hline
\end{tabular}

Having obtained our desired compounds $\mathbf{6}$ and 12, they were tested as organocatalysts in Michael addition reactions of cyclohexanone to nitrostyrene, as shown in Table 2. 
Table 2. Solvent effects on the asymmetric Michael addition of cyclohexanone to trans- $\beta$ nitrostyrene with catalysts 6 and $\mathbf{1 2 .}$

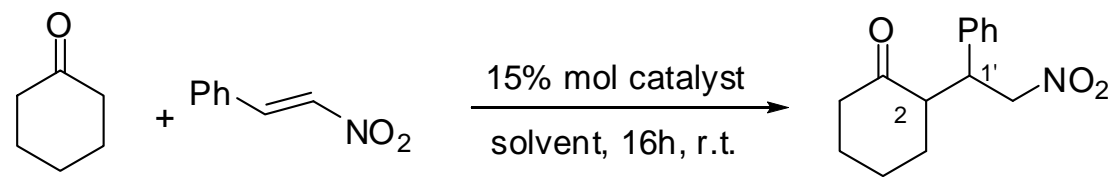

\begin{tabular}{|c|c|c|c|c|c|c|}
\hline Entry $^{[\mathbf{a}]}$ & Solv. & Catalyst & Yield [\%] $^{[\mathbf{b}]}$ & d.r.[\%] $^{[\mathbf{c}]}$ & $\mathbf{e e [ \%}^{[\mathbf{d}]}$ & Conf. \\
$\mathbf{1}$ & $\mathrm{CHCl}_{3}$ & $\mathbf{6}$ & - & - & - & - \\
$\mathbf{2}$ & $\mathrm{CHCl}_{3}$ & $\mathbf{1 2}$ & 35 & $>95$ & 38 & $2 R, 1^{\prime} S$ \\
$\mathbf{3}$ & $\mathrm{DMSO}$ & $\mathbf{6}$ & 20 & $>95$ & 69 & $2 S, 1^{\prime} R$ \\
$\mathbf{4}$ & $\mathrm{DMSO}$ & $\mathbf{1 2}$ & - & - & - & - \\
\hline
\end{tabular}

[a] For experimental conditions see the Experimental section. [b] Yield of the isolated product. [c] Determined by ${ }^{1} \mathrm{H}-\mathrm{NMR}$ spectroscopic analysis. [d] Determined by chiral high-performance liquid chromatography (HPLC) analysis (Daicel Chiralpak AD, $25 \mathrm{~cm} / 4.6 \mathrm{~mm} / 5 \mu$ ).

As can be observed, both compounds $\mathbf{6}$ and $\mathbf{1 2}$ are organocatalysts. However, their behaviour is rather different depending on the solvent chosen to carry out the reaction. It is worthy mentioning that compound 12 lead to the opposite enantiomer of $\mathbf{6}$ in the Michael addition, as a result of the stereochemistry change in C-2 position. The absolute configuration of the addition product was established by comparison of the HPLC data with the ones reported by us [21] and others [32-33].

\section{Conclusions}

The synthesis of a new chiral pyrrolidine 12, has been achieved from the same starting material, 2,3-O-iso-propylidene-D-erythronolactol through two different methodologies. In addition, the reduction of the chiral hydroxylamine into pyrrolidine has been studied under different conditions.

\section{Experimental}

\subsection{General}

${ }^{1} \mathrm{H}-\mathrm{NMR}$ and ${ }^{13} \mathrm{C}-\mathrm{NMR}$ spectra were recorded in $\mathrm{CDCl}_{3}$ at 200 and $400 \mathrm{MHz}\left({ }^{1} \mathrm{H}\right)$ or 50 and $100 \mathrm{MHz}\left({ }^{13} \mathrm{C}\right)$ on Varian $200 \mathrm{VX}$ and BRUKER DRX 400 instruments, respectively. Multiplicities were determined by DEPT experiments. IR spectra were registered using a BOMEM 100 FTIR spectrophotometer. Optical rotations were determined using a Perkin-Elmer 241 polarimeter in a $1 \mathrm{dm}$ cell and are given in units of $10-1 \mathrm{deg} \mathrm{cm}^{2} \mathrm{~g}^{-1}$. Concentrations are quoted in $\mathrm{g}$ per $100 \mathrm{~mL}$. The electron impact (EI) mass spectra were run on a VG-TS 250 spectrometer using a $70 \mathrm{eV}$ ionizing voltage. HRMS were recorded using a VG Platform (Fisons) spectrometer using Chemical Ionization (ammonia as gas) or Fast Atom Bombardment (FAB) techniques. Thin layer chromatography (tlc) was performed on aluminum sheets coated with 60 F254 silica. Sheets were visualized using iodine, UV light or $1 \%$ aqueous $\mathrm{KMnO}_{4}$ solution. Column chromatography (CC) was performed with Merck silica 
gel 60 (70-230 mesh). Solvents and reagents were generally distilled prior to use: dichloromethane (DCM) from $\mathrm{KOH}$.

\subsection{Preparation of (2S,3S,4R)-N-Benzoyl-2-phenylsulfonylmethyl-3,4-isopropylidenedioxypyrrolidine}

(10)

To a solution of pyrrolidine $6(40 \mathrm{mg}, 0.13 \mathrm{mmol})$ in pyridine $(0.5 \mathrm{~mL})$ at $0{ }^{\circ} \mathrm{C}$ was added $\mathrm{PhCOCl}$ $(20 \mu \mathrm{L})$ and the mixture was stirred for $3 \mathrm{~h}$. The reaction was quenched by the addition of water $(0.2 \mathrm{~mL})$ at $0{ }^{\circ} \mathrm{C}$ and then the mixture was extracted with EtOAc $(3 \times 10 \mathrm{~mL})$. The combined organic layers were washed with aqueous solutions of $\mathrm{CuSO}_{4}(20 \%), \mathrm{NaHCO}_{3}(5 \%)$ and brine. After drying $\left(\mathrm{Na}_{2} \mathrm{SO}_{4}\right)$, filtering, and concentrating, the crude residue was purified by flash chromatography (silica gel, n-hexane/EtOAc 8:2) to give benzoyl derivative 10 (52 mg, 97\%). IR (film) v ( $\mathrm{cm}^{-1}$ ) 3066, 2987, 2939, 1643, 1584, 1447, 1383, 1307, 1249, 1215, 1153, 1085; ${ }^{1} \mathrm{H}-\mathrm{NMR}$ (400 MHz) $\delta=8.03-7.34$ (m, $10 \mathrm{H}), 4.83(\mathrm{t}, J=5.8 \mathrm{~Hz}, 1 \mathrm{H}), 4.66-4.61(\mathrm{~m}, 2 \mathrm{H}), 3.98(\mathrm{dd}, J=14.0$ and $3.7 \mathrm{~Hz}, 1 \mathrm{H}), 3.84(\mathrm{dd}$, $J=14.0$ and $9.0 \mathrm{~Hz}, 1 \mathrm{H}), 3.59(\mathrm{~m}, 2 \mathrm{H}), 1.54(\mathrm{~s}, 3 \mathrm{H}), 1.32(\mathrm{~s}, 3 \mathrm{H}) ;{ }^{13} \mathrm{C}-\mathrm{NMR}(100 \mathrm{MHz}) \delta=171.3$, 139.7, 135.3, 133.6, 130.8, 129.1, 128.3, 128.1, 127.7, 113.1, 78.7, 77.5, 54.8, 54.5, 53.2, 27.1, 25.2; HRMS (ESI) $\mathrm{C}_{21} \mathrm{H}_{24} \mathrm{NO}_{5} \mathrm{~S}$ requires $\left(\mathrm{M}+\mathrm{H}^{+}\right)$402.1369; found 402.1364. $[\alpha]_{\mathrm{D}}^{20}=-67.1$ (c 1.4, $\mathrm{CHCl}_{3}$ ).

\subsection{Preparation of (2R,3S,4R)- $N$-Benzoyl-2-phenylsulfonylmethyl-3,4-isopropylidenedioxypyrrolidine} (11)

A solution of pyrrolidine $10(40 \mathrm{mg}, 0.10 \mathrm{mmol})$ in THF $(1 \mathrm{~mL})$ under argon at $-78{ }^{\circ} \mathrm{C}$, was added $n$-BuLi ( $75 \mu \mathrm{L}, 1.6 \mathrm{M}$ in hexanes). The resulting mixture was stirred for $3 \mathrm{~h}$, allowing to warm to rt, whereupon the reaction was quenched with saturated aqueous solution of $\mathrm{NH}_{4} \mathrm{Cl}(0.2 \mathrm{~mL})$ and extracted with EtOAc $(3 \times 10 \mathrm{~mL})$. The combined organic layers were washed with brine, dried $\left(\mathrm{Na}_{2} \mathrm{SO}_{4}\right)$, filtered, and concentrated. The resulting crude residue was purified by flash chromatography (silica gel, n-hexane/EtOAc 7:3) to obtain 11 (20 mg, 50\%). IR (film) v (cm $\left.{ }^{-1}\right)$ 3064, 2978, 2938, 1634, $1577,1413,1319,1217,1152,1074,1046,858 ;{ }^{1} \mathrm{H}-\mathrm{NMR}(400 \mathrm{MHz}) \delta=7.98-7.38(\mathrm{~m}, 10 \mathrm{H})$, 5.25-5.23 (m, 1H), $4.85(\mathrm{~m}, 1 \mathrm{H}), 4.79(\mathrm{~m}, 1 \mathrm{H}), 3.89(\mathrm{dd}, J=14.0$ and $3.6 \mathrm{~Hz}, 1 \mathrm{H}), 3.78-3.71(\mathrm{~m}, 2 \mathrm{H})$, $3.44(\mathrm{~d}, J=14.0 \mathrm{~Hz}, 1 \mathrm{H}), 1.44(\mathrm{~s}, 3 \mathrm{H}), 1.33(\mathrm{~s}, 3 \mathrm{H}) ;{ }^{13} \mathrm{C}-\mathrm{NMR}(100 \mathrm{MHz}) \delta=170.0,139.6,135.5$, 134.0, 130.2, 129.4, 128.3, 127.8, 127.2, 112.2, 82.5, 79.6, 60.2, 54.8, 54.7, 26.9, 24.9; HRMS (ESI) $\mathrm{C}_{21} \mathrm{H}_{23} \mathrm{NO}_{5} \mathrm{~S}$ requires $(\mathrm{M}+\mathrm{Na}) 424.1195$; found $424.1189 .[\alpha]_{\mathrm{D}}{ }^{20}=+33.9\left(c 1.1, \mathrm{CHCl}_{3}\right)$.

\subsection{Preparation of (2R,3S,4R)-N-Benzyl-2-phenylsulfonylmethyl-3,4-isopropylidenedioxypyrrolidine}

Scheme 2, step e: $\mathrm{LiAlH}_{4}(7 \mathrm{mg}, 0.19 \mathrm{mmol})$ was added to a solution of 11 (38 $\left.\mathrm{mg}, 0.1 \mathrm{mmol}\right)$ in dry THF $(1 \mathrm{~mL})$ at $0{ }^{\circ} \mathrm{C}$. The resulting mixture was stirred for $1 \mathrm{~h}$, allowing to warm to $\mathrm{rt}$, whereupon the reaction was quenched with wet ether, dried $\left(\mathrm{Na}_{2} \mathrm{SO}_{4}\right)$, filtered, and concentrated. The resulting crude residue was purified by flash chromatography (silica gel, n-hexane/EtOAc 8:2) to yield benzyl derivative 9 (10 mg, 30\%). IR (film) $v\left(\mathrm{~cm}^{-1}\right)$ 2983, 2942, 1454, 1377, 1307, 1209, 1148, 1086, 1054; ${ }^{1} \mathrm{H}-\mathrm{NMR}(400 \mathrm{MHz}) \delta=7.90-7.15(\mathrm{~m}, 10 \mathrm{H}), 4.70(\mathrm{~m}, 1 \mathrm{H}), 4.64(\mathrm{~m}, 1 \mathrm{H}), 3.81(\mathrm{~d}, J=13.3 \mathrm{~Hz}, 1 \mathrm{H})$, $3.55(\mathrm{~d}, J=13.3 \mathrm{~Hz}, 1 \mathrm{H}), 3.32-3.27(\mathrm{~m}, 2 \mathrm{H}), 3.13(\mathrm{dd}, J=13.5$ and $9.0 \mathrm{~Hz}, 1 \mathrm{H}), 2.87(\mathrm{dd}$, 
$J=10.7$ and $5.3 \mathrm{~Hz}, 1 \mathrm{H}), 2.68(\mathrm{~d}, J=10.7 \mathrm{~Hz}, 1 \mathrm{H}), 1.50(\mathrm{~s}, 3 \mathrm{H}), 1.28(\mathrm{~s}, 3 \mathrm{H}) ;{ }^{13} \mathrm{C}-\mathrm{NMR}(100 \mathrm{MHz}) \delta$ $=139.4,137.0,133.7,129.2$, 128.3, 128.1, 127.1, 112.4, 84.3, 78.7, 63.4, 57.3, 56.6, 55.1, 27.0, 25.0; HRMS (ESI) $\mathrm{C}_{21} \mathrm{H}_{25} \mathrm{NO}_{4} \mathrm{~S}$ requires $(\mathrm{M}+\mathrm{Na}) 410.1402$; found $410.1397 ;[\alpha]_{\mathrm{D}}{ }^{20}=+20.2\left(c 1.0, \mathrm{CHCl}_{3}\right)$.

Scheme 2, step f: To a solution of 11 (38 mg, $0.1 \mathrm{mmol})$ in dry THF (1 mL) under argon at $\mathrm{rt}$, was added $\mathrm{BH}_{3} \cdot \mathrm{THF}\left(0.12 \mathrm{~mL}, 1 \mathrm{M}\right.$ in THF). After stirring for $2 \mathrm{~h}$ at $40{ }^{\circ} \mathrm{C}$, the reaction was quenched by the addition of water $(0.3 \mathrm{~mL})$ and extracted with $\mathrm{Et}_{2} \mathrm{O}(3 \times 10 \mathrm{~mL})$. The combined organic layers were washed with $\mathrm{H}_{2} \mathrm{O}$ and brine, dried $\left(\mathrm{Na}_{2} \mathrm{SO}_{4}\right)$, filtered, and concentrated. The resulting crude residue was purified by flash chromatography (silica gel, n-hexane/EtOAc 8:2) to obtain benzyl derivative 9 (5 $\mathrm{mg}, 15 \%)$.

\subsection{Preparation of (2R,3S,4R)-2-Phenylsulfonylmethyl-3,4-isopropylidenedioxypyrrolidine (12)}

Scheme 2, step g: To a solution of pyrrolidine $9(10 \mathrm{mg}, 0.03 \mathrm{mmol})$ in $\mathrm{MeOH}(0.5 \mathrm{~mL})$ was hydrogenated in the presence of a catalytic amount of $\mathrm{Pd} / \mathrm{C}$ with a $\mathrm{H}_{2}$ balloon at room temperature for $24 \mathrm{~h}$. The catalyst was filtered through a pad of Celite ${ }^{\circledR}$ and washed with $\mathrm{MeOH}$. After concentrating, compound 12 (6 mg, 80\%) was obtained. IR (film) $v\left(\mathrm{~cm}^{-1}\right)$ 3317, 2985, 2936, 1448, 1375, 1306, 1209, 1144, 1083, 1046, 865; ${ }^{1} \mathrm{H}-\mathrm{NMR}(400 \mathrm{MHz}) \delta=7.93(\mathrm{~m}, 2 \mathrm{H}), 7.65-7.54(\mathrm{~m}, 3 \mathrm{H}), 4.67$ (dd, $J=4.4$ and $5.3 \mathrm{~Hz}, 1 \mathrm{H}), 4.57(\mathrm{~d}, J=5.3 \mathrm{~Hz}, 1 \mathrm{H}), 3.57(\mathrm{t}, J=6.4 \mathrm{~Hz}, 1 \mathrm{H}), 3.13(\mathrm{~d}, J=13.2 \mathrm{~Hz}, 1 \mathrm{H})$, $3.05(\mathrm{~d}, J=13.6 \mathrm{~Hz}, 1 \mathrm{H}), 2.69(\mathrm{dd}, J=4.4$ and $13.2 \mathrm{~Hz}, 1 \mathrm{H}), 1.44(\mathrm{~s}, 3 \mathrm{H}), 1.27(\mathrm{~s}, 3 \mathrm{H})$; ${ }^{13} \mathrm{C}-\mathrm{NMR}$ $(100 \mathrm{MHz}) \delta=139.4,133.8,129.3,128.1,111.6,85.0,84.9,60.3,57.2,51.8,26.2,24.1$; HRMS (ESI) $\mathrm{C}_{14} \mathrm{H}_{20} \mathrm{NO}_{4} \mathrm{~S}$ requires $\left(\mathrm{M}+\mathrm{H}^{+}\right) 298.1113$; found $298.1115 ;[\alpha]_{\mathrm{D}}{ }^{20}=-13.1\left(c 1.7, \mathrm{CHCl}_{3}\right)$.

\subsection{Preparation of (3S,4R)-3,4-Isopropylidenedioxypyrroline-1-oxide (13)}

To a solution of lactol $2(1.34 \mathrm{~g}, 8.54 \mathrm{mmol})$ in dry pyridine $(8.6 \mathrm{~mL})$ containing $3 \AA$ activated molecular sieves (pellets, $10 \mathrm{~g}$ ) was added a solution of $\mathrm{NH}_{2} \mathrm{OSiMe}_{2} t-\mathrm{Bu}(1.51 \mathrm{~g}, 10.25 \mathrm{mmol})$ in pyridine $(8.6 \mathrm{~mL})$ and the mixture was stirred at $\mathrm{rt}$ for $16 \mathrm{~h}$. The reaction mixture was cooled to $0{ }^{\circ} \mathrm{C}$, and methanesulfonyl chloride $(0.8 \mathrm{~mL}, 10.25 \mathrm{mmol})$ was added slowly during $40 \mathrm{~min}$. The reaction was stirred for $2 \mathrm{~h}$ at $0^{\circ} \mathrm{C}$, warmed to rt and stirred for $4 \mathrm{~h}$. The mixture was then dilueted with $\mathrm{CH}_{2} \mathrm{Cl}_{2}$ $(9 \mathrm{~mL})$, filtered through Celite ${ }^{\circledR}$, and concentrated. The resulting crude residue was purified by flash chromatography (silica gel, $\left.\mathrm{CH}_{2} \mathrm{Cl}_{2} / \mathrm{EtOAc} / \mathrm{MeOH} 15 / 7 / 1\right)$ to give pure nitrone 13 (635 mg, 50\%). IR (film) $\vee\left(\mathrm{cm}^{-1}\right) 3084,2993,2980,1579 ;{ }^{1} \mathrm{H}-\mathrm{NMR}(400 \mathrm{MHz}) \delta=6.82(\mathrm{q}, J=1.5 \mathrm{~Hz}, 1 \mathrm{H}), 5.24(\mathrm{~d}$, $J=6.2,1 \mathrm{H}), 4.86(\mathrm{ddd}, J=6.2,5.1$ and $1.5 \mathrm{~Hz}, 1 \mathrm{H}), 4.07-3.99(\mathrm{~m}, 2 \mathrm{H}), 1.40(\mathrm{~s}, 3 \mathrm{H}), 1.31$ (s, 3H); HRMS (ESI) $\mathrm{C}_{7} \mathrm{H}_{12} \mathrm{NO}_{3}$ requires $\left(\mathrm{M}+\mathrm{H}^{+}\right)$158.1785; found $158.0822 ;[\alpha]_{\mathrm{D}}{ }^{20}=-26.9\left(c 1.1, \mathrm{CH}_{2} \mathrm{Cl}_{2}\right)$.

\subsection{Preparation of (2R,3S,4R)-2-Phenylsulfonylmethyl-1-hydroxy-3,4-isopropylidenedioxypyrrolidine} (14)

To a stirred solution of $\mathrm{MeSO}_{2} \mathrm{Ph}(520 \mathrm{mg}, 2.58 \mathrm{mmol})$ in THF (4.7 mL) was added slowly $n$-BuLi $\left(1.9 \mathrm{~mL}, 2.58 \mathrm{mmol}\right.$ ) and the mixture was reacted at $0{ }^{\circ} \mathrm{C}$ for $10 \mathrm{~min}$. Afterwards, the reaction mixture was cooled to $-78^{\circ} \mathrm{C}$ and stirred for $10 \mathrm{~min}$ at this temperature. Then, it was added into a solution of nitrone $13(320 \mathrm{mg}, 2.03 \mathrm{mmol})$ in THF $(6.7 \mathrm{~mL})$ and the mixture was stirred at $-78{ }^{\circ} \mathrm{C}$ for $30 \mathrm{~min}$ and then for $2 \mathrm{~h}$ allowing to warm to $\mathrm{rt}$. The reaction was quenched with saturated aqueous solution of 
$\mathrm{NH}_{4} \mathrm{Cl}$ and the product was extracted with EtOAc $(3 \times 15 \mathrm{~mL})$. The combined organic layers were washed with brine, dried $\left(\mathrm{Na}_{2} \mathrm{SO}_{4}\right)$, filtered, and concentrated. The resulting crude residue was purified by flash chromatography (silica gel, n-hexane/EtOAc 1:1) to obtain hydroxylamine 14 (300 mg, 48\%). IR (film) $\vee\left(\mathrm{cm}^{-1}\right) 3428,3207,2987,2925,2856,1581,1442,1385,1295,1131,1074,845 ;{ }^{1} \mathrm{H}-\mathrm{NMR}$ $(400 \mathrm{MHz}) \delta=7.96(\mathrm{~m}, 2 \mathrm{H}), 7.67-7.53(\mathrm{~m}, 3 \mathrm{H}), 6.25(\mathrm{~s}, 1 \mathrm{H}), 4.75(\mathrm{~m}, 1 \mathrm{H}), 4.62(\mathrm{dd}, J=4.2$ and $6.0 \mathrm{~Hz}, 1 \mathrm{H}), 3.69(\mathrm{dd}, J=6.4$ and $14.0 \mathrm{~Hz}, 1 \mathrm{H}), 3.44(\mathrm{~m}, 1 \mathrm{H}), 3.37(\mathrm{~m}, 1 \mathrm{H}), 3.25(\mathrm{dd}, J=6.8$ and 14.0 $\mathrm{Hz}, 1 \mathrm{H}), 3.12(\mathrm{dd}, J=4.4$ and $12.4 \mathrm{~Hz}, 1 \mathrm{H}), 1.43(\mathrm{~s}, 3 \mathrm{H}), 1.27(\mathrm{~s}, 3 \mathrm{H}) ;{ }^{13} \mathrm{C}-\mathrm{NMR}(100 \mathrm{MHz})$ $\delta=139.4,133.9,129.3,128.1,113.7,82.2,77.2,67.3,62.3,54.1,26.7,24.7$; HRMS (ESI) $\mathrm{C}_{14} \mathrm{H}_{19} \mathrm{NO}_{5} \mathrm{~S}$ requires $(\mathrm{M}+\mathrm{Na}) 336.0882$; found 336.0877; $[\alpha]_{\mathrm{D}}{ }^{20}=-20.8\left(c 2.2, \mathrm{CHCl}_{3}\right)$.

\subsection{Preparation of (2S,3S,4R)-2-Phenylsulfonylmethyl-3,4-isopropylidenedioxypyrrolidine (6)}

Scheme 3, step c: A stirred solution of hydroxylamine $14(50 \mathrm{mg}, 0.16 \mathrm{mmol})$ in a 12:1 solution of $\mathrm{HCl} / \mathrm{MeOH}(1 \mathrm{~mL})$ was hydrogenated in the presence of a catalytic amount of $\mathrm{Pd}(\mathrm{OH})_{2} / \mathrm{C}$, at a hydrogen pressure of $4 \mathrm{~atm}$ for $48 \mathrm{~h}$. The catalyst was filtered through a pad of Celite, ${ }^{\circledR}$ washed with $\mathrm{MeOH}$ and concentrated. The product was purified by flash chromatography (silica gel, nhexane/EtOAc 1:1) to provide pyrrolidine 6 (13 mg, 27\%). IR (film) $v\left(\mathrm{~cm}^{-1}\right)$ 3000, 2936, 1447, 1381, 1308, 1148, 1086, $650 \mathrm{~cm}^{-1}$; ${ }^{1} \mathrm{H}-\mathrm{NMR}(400 \mathrm{MHz}) \delta=7.93(\mathrm{~m}, 2 \mathrm{H}), 7.69-7.50$ (m, 3H), 4.67 (dd, $J=4.0$ and $5.3 \mathrm{~Hz}, 1 \mathrm{H}), 4.54(\mathrm{dd}, J=4.0$ and $5.3 \mathrm{~Hz}, 1 \mathrm{H}), 3.57(\mathrm{dd}, J=5.0$ and $14.0 \mathrm{~Hz}, 1 \mathrm{H}), 3.36$ $(\mathrm{dd}, J=7.0$ and $14.0 \mathrm{~Hz}, 1 \mathrm{H}), 3.22(\mathrm{~m}, 1 \mathrm{H}), 3.13(\mathrm{~d}, J=12.7 \mathrm{~Hz}, 1 \mathrm{H}), 2.69$ (dd, $J=4.0$ and $12.7 \mathrm{~Hz}$, $1 \mathrm{H}), 2.20(\mathrm{~s}, 1 \mathrm{H}), 1.41(\mathrm{~s}, 3 \mathrm{H})$ and $1.25(\mathrm{~s}, 3 \mathrm{H}) ;{ }^{13} \mathrm{C}-\mathrm{NMR}(100 \mathrm{MHz}) \delta=139.7,133.7,129.2,127.2$, 111.1, 81.0, 80.8, 57.1, 55.9, 52.6, 25.7, 24.0; HRMS (ESI) $\mathrm{C}_{14} \mathrm{H}_{20} \mathrm{NO}_{4} \mathrm{~S}$ requires $\left(\mathrm{M}+\mathrm{H}^{+}\right)$298.1113; found 298.1128; $[\alpha]_{\mathrm{D}}{ }^{20}=-37.3\left(c 0.5, \mathrm{CHCl}_{3}\right)$.

(Scheme 3, step d): A stirred solution of hydroxylamine 14 (66 mg, $0.21 \mathrm{mmol}$ ) in $1 \mathrm{~mL}$ of $\mathrm{MeOH}$ was hydrogenated in the presence of a catalytic amount of $\mathrm{Pd} / \mathrm{C}$ with a $\mathrm{H}_{2}$ balloon at room temperature for $24 \mathrm{~h}$. The catalyst was filtered through a pad of Celite, ${ }^{\circledR}$ washed with $\mathrm{MeOH}$ and concentrated. The product was purified by flash chromatography (silica gel, n-hexane/EtOAc 1:1) to provide pyrrolidine $6(24 \mathrm{mg}, 39 \%)$.

\subsection{Preparation of (2R,3S,4R)-2-Phenylsulfonylmethyl-1-hydroxy-3,4-isopropylidenedioxypyrrolidine} (15)

(Scheme 3, step e): To a stirred solution of hydroxylamine $14(32.1 \mathrm{mg}, 0.10 \mathrm{mmol})$ in a 2:1 solution of EtOH /saturated aqueous $\mathrm{NH}_{4} \mathrm{Cl}(18.5 \mathrm{~mL})$, powdered indium $(14 \mathrm{~g}, 0.12 \mathrm{mmol})$ was added and the mixture was heated under reflux. After $24 \mathrm{~h}$ the reaction mixture was cooled, filtered through Celite, ${ }^{\circledR}$ and concentrated under reduced pressure. A saturated aqueous $\mathrm{Na}_{2} \mathrm{CO}_{3}$ solution $(5 \mathrm{~mL})$ was then added, and the product was extracted with EtOAc $(3 \times 15 \mathrm{~mL})$. The combined organic layers were washed with brine, dried $\left(\mathrm{Na}_{2} \mathrm{SO}_{4}\right)$, filtered, and concentrated. The resulting crude residue was purified by flash chromatography (silica gel, hexane/EtOAc 1:1) to obtain hydroxylamine 15 (28.8 $\mathrm{mg}, 92 \%)$. IR (film) $v\left(\mathrm{~cm}^{-1}\right) 3448,2985,2933,2854,1448,1383,1306,1085,856 ;{ }^{1} \mathrm{H}-\mathrm{NMR}(400 \mathrm{MHz}) \delta=7.97$ $(\mathrm{m}, 2 \mathrm{H}), 7.67-7.52(\mathrm{~m}, 3 \mathrm{H}), 6.27(\mathrm{~s}, 1 \mathrm{H}), 4.60(\mathrm{~m}, 2 \mathrm{H}), 3.70(\mathrm{dd}, J=8.4$ and $14 . \mathrm{o} \mathrm{Hz}, 1 \mathrm{H}), 3.50-3.38$ $(\mathrm{m}, 2 \mathrm{H}), 3.05(\mathrm{~m}, 1 \mathrm{H}), 2.70(\mathrm{dd}, J=4.4$ and $11.0 \mathrm{~Hz}, 1 \mathrm{H}), 1.37(\mathrm{~s}, 3 \mathrm{H}), 1.22(\mathrm{~s}, 3 \mathrm{H}) ;{ }^{13} \mathrm{C}-\mathrm{NMR}$ 
$(100 \mathrm{MHz}) \delta=139.9,134.1,129.5,128.3,111.1,77.2,76.4,65.9,62.2,54.5,25.9,24.4$; HRMS (ESI) $\mathrm{C}_{14} \mathrm{H}_{19} \mathrm{NO}_{5} \mathrm{~S}$ requires $(\mathrm{M}+\mathrm{Na}) 336.0882$; found 336.0895; $[\alpha]_{\mathrm{D}}{ }^{20}=-10.4\left(c 1.3, \mathrm{CHCl}_{3}\right)$.

Scheme 3, step f: To a stirred solution of hydroxylamine $14(69 \mathrm{mg}, 0.22 \mathrm{mmol})$ in a solution of $\mathrm{MeOH} / \mathrm{NH}_{4} \mathrm{Cl}_{\text {sat }}(3.4 / 5 \mathrm{~mL})$, powdered $\mathrm{Zn}(29 \mathrm{mg}, 0.44 \mathrm{mmol})$ was added at $20{ }^{\circ} \mathrm{C}$ and the mixture was stirred for $6 \mathrm{~h}$. The solvent was evaporated under vacuum and a saturated aqueous solution of $\mathrm{Na}_{2} \mathrm{CO}_{3}(1.5 \mathrm{~mL})$ was added. The mixture was extracted with EtOAc $(3 \times 15 \mathrm{~mL})$ and the combined organic layers were washed with brine, dried $\left(\mathrm{Na}_{2} \mathrm{SO}_{4}\right)$, filtered, and concentrated. The resulting crude residue was purified by flash chromatography (silica gel, n-hexane/EtOAc 1:1) to obtain hydroxylamine 15 (34 mg, 50\%).

\subsection{Preparation of (2R,3S,4R)-2-Phenylsulfonylmethyl-3,4-isopropylidenedioxypyrrolidine (12)}

Scheme 3, step g, Table 1, entry 8, as example: To a stirred solution of hydroxylamine 14 (852 $\mathrm{mg}$, $2.58 \mathrm{mmol})$, in methanol $(37 \mathrm{~mL})$, a saturated solution of $\mathrm{NH}_{4} \mathrm{Cl}(56 \mathrm{~mL})$, powdered $\mathrm{Zn}(712 \mathrm{mg}$, $10.9 \mathrm{mmol})$ and a catalytic amount of indium dust $(20 \mathrm{mg})$ were added at $20{ }^{\circ} \mathrm{C}$. The mixture was stirred for $6 \mathrm{~h}$. The solvent was evaporated under vacuum and a saturated aqueous solution of $\mathrm{Na}_{2} \mathrm{CO}_{3}$ $(5 \mathrm{~mL})$ was added. The mixture was extracted with EtOAc $(3 \times 15 \mathrm{~mL})$. The combined organic layers were washed with brine, dried $\left(\mathrm{Na}_{2} \mathrm{SO}_{4}\right)$, filtered, and concentrated. The resulting crude residue was purified by flash chromatography (silica gel, n-hexane/EtOAc 1:1) to obtain pyrrolidines 12 (248 mg, $35 \%)$ and $6(13 \mathrm{mg}, 2 \%)$.

\subsection{1. (2S,1'R)-2-[1'-Phenyl-2'-nitroethyl]-cyclohexanone}

To a suspension of catalyst $6(10 \mathrm{mg}, 15 \%)$ and $0.438 \mathrm{~mL}(4.40 \mathrm{mmol})$ of cyclohexanone in $3.5 \mathrm{~mL}$ of DMSO was added $33 \mathrm{mg}(0.22 \mathrm{mmol})$ of trans- $\beta$ nitrostyrene. The resulting mixture was allowed to stir at room temperature for $16 \mathrm{~h}$, whereupon the reaction was quenched with saturated aqueous ammonium chloride $(2 \mathrm{~mL})$ and the aqueous layers were extracted with ethyl acetate. The combined organic layers were dried over $\mathrm{Na}_{2} \mathrm{SO}_{4}$, filtered and evaporated in vacuo and the resulting residue was purified by flash column chromatography using (hexane/EtOAc, 9/1) to give the title compound, as a white solid (11mg, 20\%). ${ }^{1} \mathrm{H}-\mathrm{NMR}(400 \mathrm{MHz}) \delta 7.34-7.16(\mathrm{~m}, 5 \mathrm{H}, \mathrm{Ph}), 4.93(\mathrm{dd}, J=12.5 \mathrm{and} 4.5 \mathrm{~Hz}$, $\left.1 \mathrm{H}, \mathrm{CH}_{2}\right), 4.60\left(\mathrm{dd}, J=12.5\right.$ and $\left.9.9 \mathrm{~Hz}, 1 \mathrm{H}, \mathrm{CH}_{2}\right), 3.76(\mathrm{~m}, 1 \mathrm{H}, \mathrm{CH}), 2.69(\mathrm{~m}, 1 \mathrm{H}, \mathrm{CH}), 2.50-1.52$ $\left(\mathrm{m}, 8 \mathrm{H}, 4 \mathrm{CH}_{2}\right)$. The absolute configuration was established by comparison with reported HPLC data

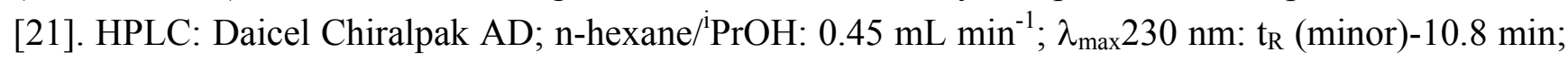
$\mathrm{t}_{\mathrm{R}}$ (major)-13.1 $\mathrm{min}$.

\subsection{2. (2R,1'S)-2-[1'-Phenyl-2'-nitroethyl]-cyclohexanone}

To a suspension of catalyst $12(10 \mathrm{mg}, 15 \%)$ and $0.438 \mathrm{~mL}(4.40 \mathrm{mmol})$ of cyclohexanone in $3.5 \mathrm{~mL}$ of $\mathrm{CHCl}_{3}$ was added $33 \mathrm{mg}(0.22 \mathrm{mmol})$ of trans- $\beta$ nitrostyrene. The resulting mixture was allowed to stir at room temperature for $16 \mathrm{~h}$, whereupon the reaction was quenched with saturated aqueous ammonium chloride $(2 \mathrm{~mL})$ and the aqueous layers were extracted with ethyl acetate. The combined organic layers were dried over $\mathrm{Na}_{2} \mathrm{SO}_{4}$, filtered and evaporated in vacuo and the resulting residue was purified by flash column chromatography using (n-hexane/EtOAc, 9/1) to give the title 
compound, as a white solid (22mg, 35\%). The absolute configuration was established by comparison with reported HPLC data [21]. HPLC: Daicel Chiralpak AD; n-hexane/ ${ }^{i} \mathrm{PrOH}: 0.45 \mathrm{~mL} \mathrm{~min}{ }^{-1} ; \lambda_{\max } 230$ $\mathrm{nm}: \mathrm{t}_{\mathrm{R}}$ (major)-10.5 min; $\mathrm{t}_{\mathrm{R}}$ (minor)-12.9 $\mathrm{min}$.

\section{Acknowledgements}

Financial support for this work came from FSE, Spanish MEC (CTQ2006-08296/BQU, CTQ200911172/BQU) and Junta de Castilla y León (Spain) GR-178, (SA001A09). The authors thank also A. M. Lithgow for the NMR spectra and César Raposo for the mass spectra. M.G.N. is grateful for a FPU doctoral fellowship of the Spanish MEC and M.F.F. to Junta de Castilla y León.

\section{References and Notes}

1. Dalko, P.I.; Moisan, L. Enantioselective Organocatalysis. Angew. Chem. Int. Ed. Engl. 2001, 113, 3726-3748.

2. List, B. Asymmetric Aminocatalysis. Synlett 2001, 1675-1686.

3. Brown, S.P.; Brochu, M.P.; Sinz, C.J.; MacMillan, D.W.C. The Direct and Enantioselective Organocatalytic -Oxidation of Aldehydes. J. Am. Chem. Soc. 2003, 125, 10808-10809.

4. Pidathala, C.; Hoang, L.; Vignola, N.; List, B. Direct Catalytic Asymmetric Enolexo Aldolizations. Angew. Chem. Int. Ed. Engl. 2003, 42, 2785-2788.

5. Berkessel, A.; Gröger, H. Asymmetric Organocatalysis. From Biomimetic Concepts to Applications in Asymmetric Synthesis; Wiley-VCH: Weinheim, Germany, 2005.

6. MacMillan, D.W.C. The advent and development of organocatalysis. Nature 2008, 455, 304-308.

7. Tanaka, F.; Mase, N.; Barbas, C.F. Design and Use of Fluorogenic Aldehydes for Monitoring the Progress of Aldehyde Transformations. J. Am. Chem. Soc. 2004, 126, 3692-3693.

8. Sekiguchi, Y.; Sasaoka, A.; Shimomoto, A.; Fujioka, S.; Kotsuki, H. High-Pressure-Promoted Asymmetric Aldol Reactions of Ketones with Aldehydes Catalyzed by L-Proline. Synlett 2003, 1655-1658.

9. Hayashi, Y.; Yamaguchi, J.; Sumiya, T.; Shoji, M. Direct Proline-Catalyzed Asymmetric Aminoxylation of Ketones. Angew. Chem. Int. Ed. Engl. 2004, 43, 1112-1115.

10. List, B. Proline-catalyzed asymmetric reactions. Tetrahedron 2002 58, 5573-5590.

11. Mangion, I.K.; Northrup, A.B.; MacMillan, D.W.C. The Importance of Iminium Geometry Control in Enamine Catalysis: Identification of a New Catalyst Architecture for AldehydeAldehyde Couplings. Angew. Chem. Int. Ed. Engl. 2004, 43, 6722-6724.

12. Cobb, A.J.A.; Longbottom, D.A.; Shaw, D.M.; Ley, S.V. 5-Pyrrolidin-2-yltetrazole as an asymmetric organocatalyst for the addition of ketones to nitro-olefins. Chem. Commun. 2004, 1808-1809.

13. Wang, W.; Wang, J.; Li, H. Direct, Highly Enantioselective Pyrrolidine Sulfonamide Catalyzed Michael Addition of Aldehydes to Nitrostyrenes. Angew. Chem. Int. Ed. Engl. 2005, 44, 1369-1371.

14. Andrey, O.; Alexakis, A.; Tomassini, A. Bernardinelli, G. The Use of N-Alkyl-2,2'-bipyrrolidine Derivatives as Organocatalysts for the Asymmetric Michael Addition of Ketones and Aldehydes to Nitroolefins. Adv. Synth. Catal. 2004, 346, 1147-1168. 
15. List, B.; Lerner, R.A.; Barbas, C.F. Proline-Catalyzed Direct Asymmetric Aldol Reactions. J. Am. Chem. Soc. 2000, 122, 2395-2396.

16. Diez, D.; Beneitez, M.T.; Marcos, I.S.; Garrido, N.M.; Basabe, P.; Urones, J.G. Enantioselective Synthesis of a 2,3,4-Trisubstituted Pyrrolidine from 1-Hydroxymethyl-4-phenylsulfonylbutadiene. Synlett 2001, 655-657.

17. Diez, D.; Beneitez, M.T.; Moro, R.F.; Marcos, I.S.; Basabe, P.; Garrido, N.M.; Urones, J.G. Regio- and stereoselective ring opening of epoxides Enantioselective synthesis of 2,3,4trisubstituted five-membered heterocycles. Tetrahedron Asymmetry 2002, 13, 639-646.

18. Diez, D.; Beneitez, M.T.; Moro, R.F.; Marcos, I.S.; Basabe, P.; Garrido, N.M.; Urones, J.G. Synthesis of Vinylsulfone Derivatives of Sugars: An Easy Preparation of $(2 R, 3 S, 4 E)-5-$ Benzenesulfonyl-2,3-iso-propylidene-dioxy-pent-4-en-1-yl-tosylate. Synlett 2003, 729-731.

19. Diez, D.; Núñez, M.G.; Moro, R.F.; Marcos, I.S.; Basabe, P.; Broughton, H.B.; Urones, J.G. Organocatalytic Synthesis of an Alkyltetrahydropyran. Synlett 2009, 390-394.

20. Nising, C.F.; Bräse, S. The oxa-Michael reaction: From recent developments to applications in natural product synthesis. Chem. Soc. Rev. 2008, 37, 1218-1228.

21. Diez. D; Gil. M.J.; Moro. R.F.; Marcos. I.S.; García P.; Basabe. P.; Garrido. N.M.; Broughton H.B, Urones. J.G. A new class of chiral pyrrolidine for asymmetric Michael addition reactions. New mechanism via simple 4+2 type attack of the enamine on the trans-nitrostyrene. Tetrahedron 2007, 63, 740-747.

22. Diez, D.; Gil, M.J.; Moro, R.F.; Garrido, N.M.; Marcos, I.S.; Basabe, P.; Sanz, F.; Broughton, H.B.; Urones, J.G. Chemistry of sulfones: Synthesis of a new chiral nucleophilic catalyst. Tetrahedron Asymmetry 2005, 16, 2980-2985.

23. Cicchi, S.; Marradi, M.; Vogel, P.; Goti, A. One-Pot Synthesis of cyclic Nitrones and Their Conversion to Pyrrolizidines: 7a-epi-Crotanecine Inhibits -Mannosidases. J. Org. Chem, 2006, 71, 1614-1619.

24. Cicchi, S.; Corsi, M.; Brandi, A.; Goti, A. Straigtforward Synthesis of Enantiomerically Pure $(3 S, 4 R)$-and $(3 R, 4 S)-3,4-$ Isopropylidendioxypyrroline 1-Oxide, Precursors of Fucntionalized cisDihydroxy Azaheterocycles, by a Novel "One-Pot" Procedure J. Org. Chem. 2002, 67, 1678-1681.

25. Revuelta, J.;Cicchi, S.; Goti, A.; Brandi, A. Enantiopure Cyclic Nitrones: A Useful Class of Building Blocks for Asymmetric Syntheses. Synthesis 2007, 485-504.

26. McCaig, A.E.; Meldrum, K.P.; Wightman, R.H. Synthesis of Trihydroxylated Pyrrolizidines using Cycloaddition Reactions of Functionalized Cyclic Nitrones, and the Synthesis of (+)- and (-)Lentiginosine. Tetrahedron 1998, 54, 9429-9446.

27. Hall, A.; Meldrum, K.P.; Therond, P.R.; Wightman, R.H. Synthesis of Hydroxylated Pyrrolizidines Related to Alexine using Cycloaddition Reactions of Functionalized Cyclic Nitrones. Synlett 1997, 123-125.

28. Closa, M.; Wightman, R.H. Synthesis of (3S,4R)-3,4-Isopropylidenedioxy-1-pyrroline- $N$-oxide, an Enantiopure Functionalized cyclic nitrone; Cycloaddition reactions with Dimethyl maleate and Dimethyl fumarate. Synth. Commun. 1998, 28, 3443-3450. 
29. Cardona, F.; Moreno, G.; Guarna, F.; Vogel, P.; Schuetz, C.; Merino, P.; Goti, A. New Concise Total Synthesis of (+)-Lentiginosine and Some Structural Analogues. J. Org. Chem. 2005, 70, 6552-6555.

30. Brandi, A.; Cardona, F.; Cicchi, S. Cordero, F.M.; Goti, A. Stereocontrolled Cyclic Nitrone Cycloaddition Strategy for the Synthesis of Pyrrolizidine and Indolizine Alkaloids. Chem. Eur. J. 2009, 15, 7808-7821.

31. Cicchi, S.; Bonami, M.; Cardona, F.; Revuelta, J.; Goti, A. Indium-Mediated Reduction of Hydroxylamines to Amines. Org. Lett. 2003, 5, 1773-1776.

32. Cobb, A.J.A.; Shaw, D.M.; Longbottom, D.A.; Gold, J.B.; Ley, S.V. Organocatalysis with proline derivatives: Improved catalysts for the asymmetric Mannich, nitro-Michael and aldol reactions. Org. Biomol. Chem. 2005, 3, 84-96.

33. Alza, E.; Cambeiro, X.C.; Jimeno, C.; Pericàs, M.A. Highly Enantioselective Michael Additions in Water Catalyzed by a PS-Supported Pyrrolidine. Org. Lett. 2007, 9, 3717-3720.

Sample Availability: Samples of the compounds $\mathbf{6}$ and $\mathbf{1 2}$ are available from the authors.

(C) 2010 by the authors; licensee Molecular Diversity Preservation International, Basel, Switzerland. This article is an open-access article distributed under the terms and conditions of the Creative Commons Attribution license (http://creativecommons.org/licenses/by/3.0/). 